А.А. Зимирова, М.В. Поспелов, А.В. Иванова, Л.Н. Дмитриева, Е.А. Чумачкова, И. Г. Карнаухов, С. А. Щербакова, В. В. Кутырев

\title{
Анализ динамики эпидемического процесса COVID-19 в мире за неделю с 08.01.2022 г. по 14.01.2022 г.
}

ФКУЗ Российский научно-исследовательский противочумный институт «Микроб» Роспотребнадзора, Саратов, Российская Федерация

В обзоре представлен анализ эпидемиологической ситуации в странах мира по COVID-19, за неделю с 08.01.2022 г. по 14.01.2022 г.

Анализ проведен на основании данных следующих ресурсов:

1. www.worldometers.info/coronavirus/

2. tass.ru/pandemiya-covid-19

3. www.skyscanner.ru/travel-restrictions

4. reopen.europa.eu/en/map/LVA/7001

5. intelyse.com/coronavirus-travel-restrictions/

6.gisanddata.maps.arcgis.com/apps/dashboards/bda7594740fd40299423467b4 $8 \mathrm{e} 9 \mathrm{ecf6}$ 
Всего в мире зарегистрирован 320077391 случай заболевания (41839 на 1 млн. населения); прирост за неделю составил 19923471 случай (2604,3 на 1 млн. населения) - 6,6\%. Всего в мире зарегистрировано 5522999 летальных исходов (721,9 на 1 млн. населения); прирост за неделю составил 48513 случаев (6,3 на 1 млн. населения) $-0,9 \%$.

За неделю с 8 по 14 января 2022 г. показатель прироста новых случаев в сравнении с предыдущей неделей (с 1 по 7 января) увеличился с 5,5\% до 6,6\% (рис. 1; таб.1). Недельный прирост числа летальных исходов за анализируемую неделю не изменился и составил $0,9 \%$.

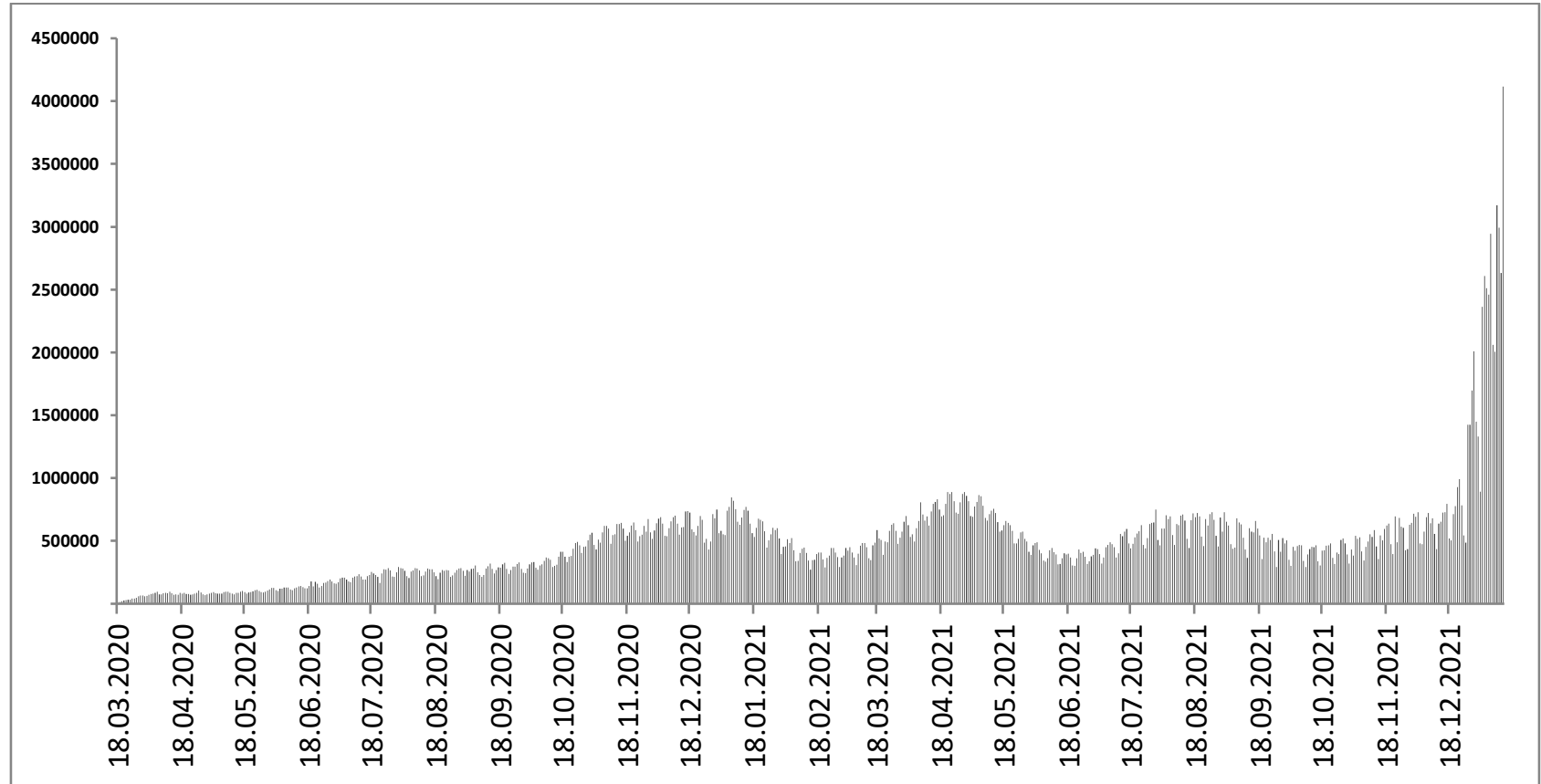

Рисунок 1 - Ежедневный прирост подтвержденных случаев в мире 
Таблица 1 - Еженедельный прирост случаев за последние полгода

\begin{tabular}{|c|c|c|c|c|c|}
\hline Неделя & $\begin{array}{c}\text { Недель- } \\
\text { ный при- } \\
\text { рост } \\
\text { (случаев) }\end{array}$ & $\begin{array}{c}\text { Недель- } \\
\text { ный при- } \\
\text { рост (\%) }\end{array}$ & Неделя & $\begin{array}{c}\text { Недель- } \\
\text { ный при- } \\
\text { рост (слу- } \\
\text { чаев) }\end{array}$ & $\begin{array}{c}\text { Недель- } \\
\text { ный при- } \\
\text { рост (\%) }\end{array}$ \\
\hline $17-23$ июля & 3656571 & 1,9 & $16-22$ октября & 2885362 & 1,2 \\
\hline $24-30$ июля & 3978967 & 2,1 & $23-29$ октября & 3022350 & 1,2 \\
\hline $\begin{array}{c}31 \text { июля -6 ав- } \\
\text { густа }\end{array}$ & 4295399 & 2,2 & $\begin{array}{c}30 \text { октябяя }-5 \\
\text { ноября }\end{array}$ & 3064395 & 1,2 \\
\hline $7-13$ августа & 4386968 & 2,3 & $6-12$ ноября & 3322096 & 1,3 \\
\hline $14-20$ августа & 4416659 & 2,2 & $13-19$ ноября & 3665348 & 1,5 \\
\hline $21-27$ августа & 4617376 & 2,2 & $20-26$ ноября & 4475143 & 1,8 \\
\hline $\begin{array}{c}28 \text { августа }-3 \\
\text { сентября }\end{array}$ & 4457642 & 2,1 & $\begin{array}{c}27 \text { ноября - } 3 \text { де- } \\
\text { кабря }\end{array}$ & 4144135 & 1,6 \\
\hline $4-10$ сентября & 4108660 & 1,9 & $4-10$ декабря & 4312210 & 1,6 \\
\hline $11-17$ сентября & 3881581 & 1,7 & $11-17$ декабря & 4418121 & 1,6 \\
\hline $18-24$ сентября & 3544821 & 1,6 & $18-24$ декабря & 5257704 & 1,9 \\
\hline $\begin{array}{c}25 \text { сентября - } 1 \\
\text { октября }\end{array}$ & 3179984 & 1,4 & $25-30$ декабря & 6357670 & 2,3 \\
\hline $2-8$ октября & 2991475 & 1,3 & $1-7$ января 2022 & 15619644 & 5,5 \\
\hline $9-15$ октября & 2829038 & 1,2 & $8-14$ января & 19923471 & 6,6 \\
\hline
\end{tabular}




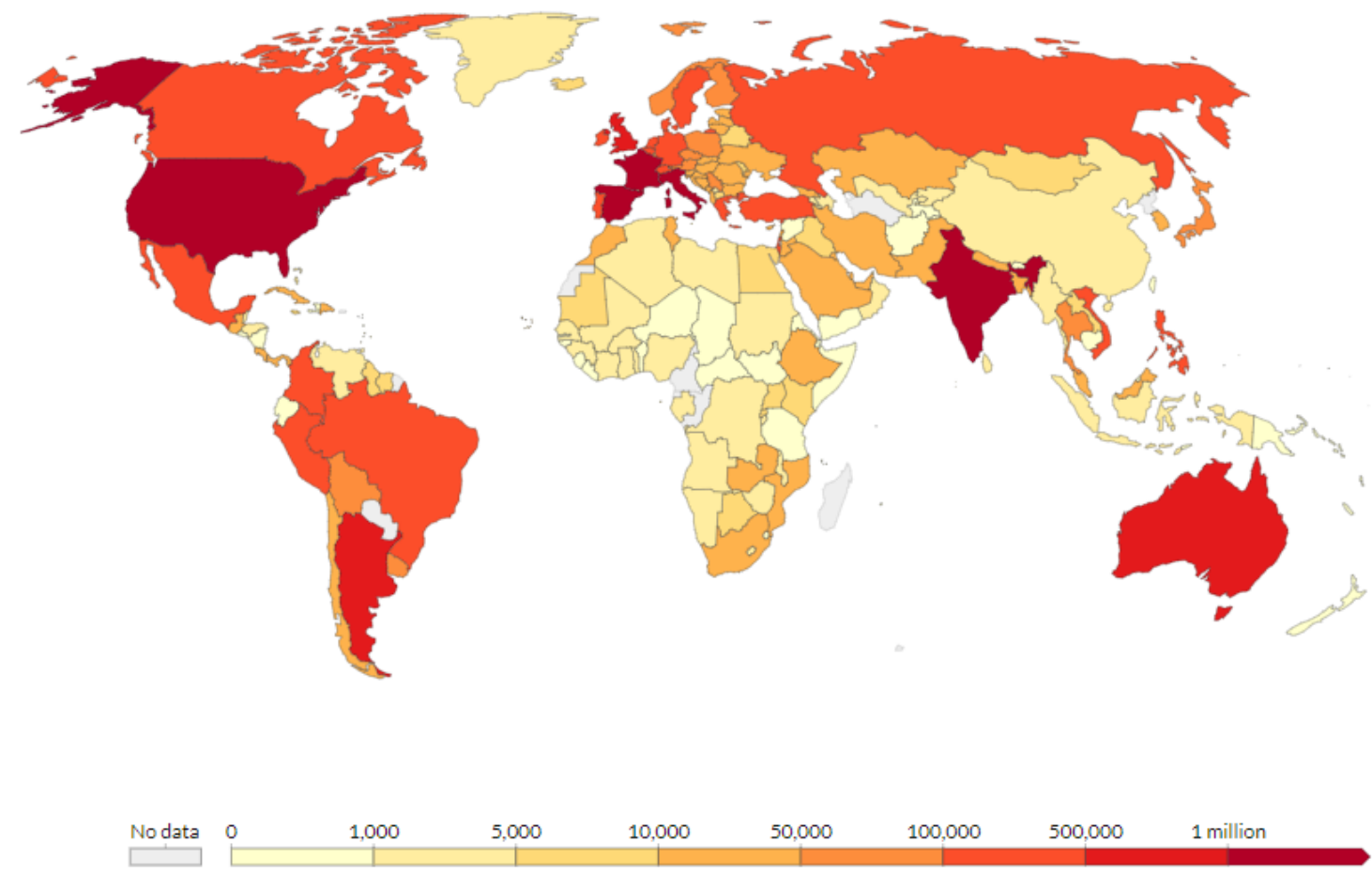

Рисунок 2 - Количество зарегистрированных случаев с 08.01.2022 г. по 14.01.2022 г.

За последнюю неделю в мире каждый день число новых случаев увеличивалось на 2 - 3 млн. В общей структуре заболеваемости за неделю с 8 по 14 января 2022 г. наибольшая доля новых случаев приходится на Европейский регион (45,1\%, показатель снизился на 6,5\%). Доля случаев в Американском регионе за неделю возросла на 1,4\% и составила 39,2\%. Доля Юго-Восточной Азии возросла на 4,2\% в сравнении с предыдущей неделей и составила 6,7\%. Доля Западно-Тихоокеанского региона увеличилась на $1,7 \%$ в сравнении с предыдущей неделей - 6,5\%. За анализируемый период доля Восточно - Средиземноморского региона возросла на $0,3 \%$ и составила $1,6 \%$. Наименьший удельный вес новых случаев заболевания приходится на страны Африканского региона $-0,9 \%$, доля уменьшилась на 1,2\% по сравнению с предыдущей неделей. 


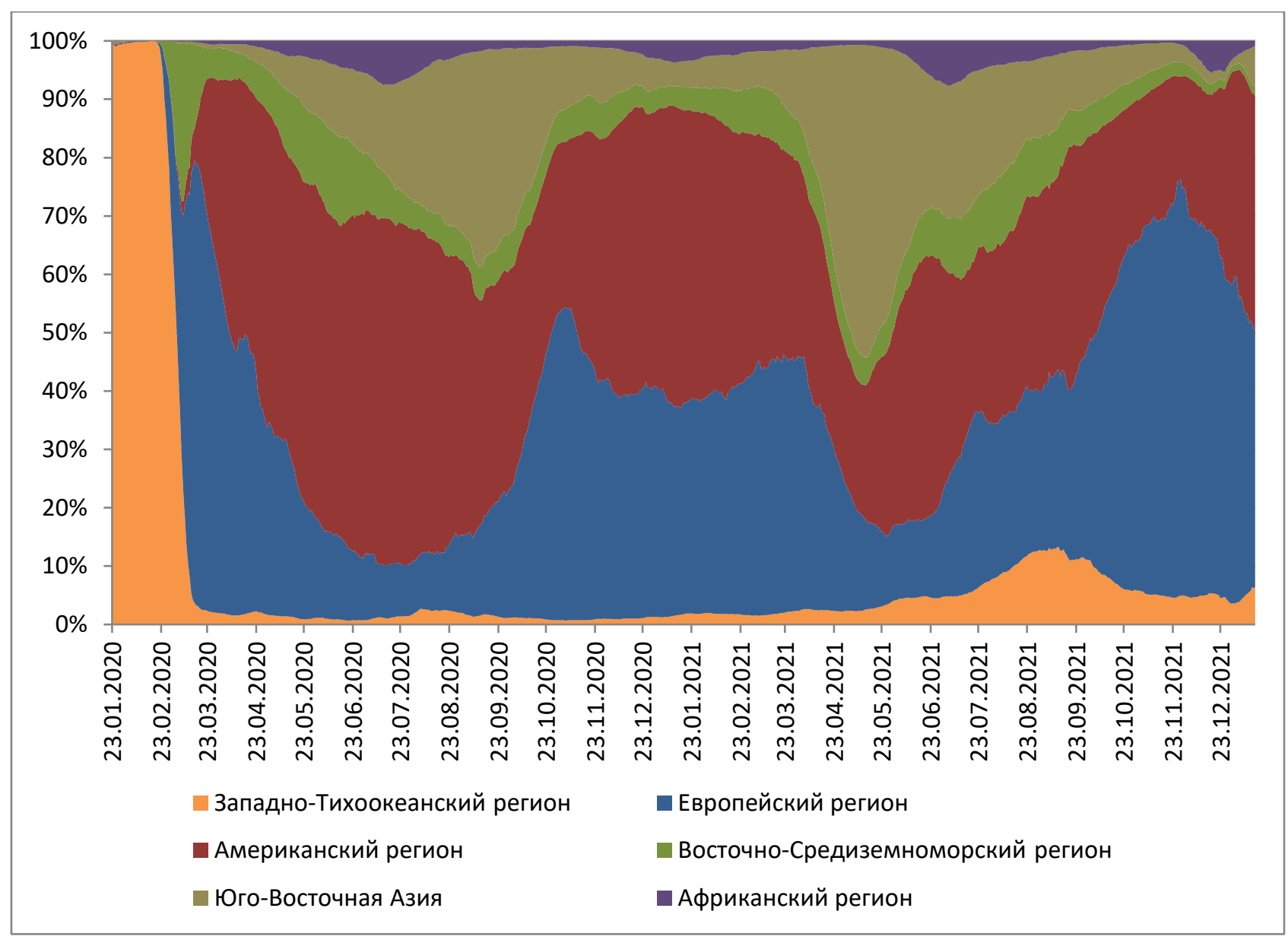

Рисунок 3 - Доля регионов мира в ежедневном приросте случаев заболевания 
Таблица 2 - Средняя доля региона от ежедневного прироста в мире

\begin{tabular}{|c|c|c|c|c|c|c|c|c|c|c|}
\hline Регионы ВОЗ & $\begin{array}{c}6-12 \\
\text { нояб- } \\
\text { ря }\end{array}$ & $\begin{array}{c}13- \\
19 \\
\text { нояб- } \\
\text { ря }\end{array}$ & $\begin{array}{c}20- \\
26 \\
\text { нояб- } \\
\text { ря }\end{array}$ & $\begin{array}{c}27 \\
\text { нояб- } \\
\text { ря-3 } \\
\text { де- } \\
\text { кабря }\end{array}$ & $\begin{array}{c}4-10 \\
\text { де- } \\
\text { кабря }\end{array}$ & $\begin{array}{c}11- \\
17 \\
\text { де- } \\
\text { кабря }\end{array}$ & $\begin{array}{c}18- \\
24 \\
\text { де- } \\
\text { кабря }\end{array}$ & $\begin{array}{c}25- \\
30 \\
\text { де- } \\
\text { кабря }\end{array}$ & $\begin{array}{c}1-7 \\
\text { янва- } \\
\text { ря }\end{array}$ & $\begin{array}{c}\mathbf{8}-\mathbf{1 4} \\
\text { янва- } \\
\text { ря }\end{array}$ \\
\hline $\begin{array}{c}\text { Западно- } \\
\text { Тихоокеан- } \\
\text { ский регион }\end{array}$ & 5,2 & 5 & 4,8 & 5 & 4,9 & 5,4 & 4,7 & 4,5 & 4,8 & 6,5 \\
\hline $\begin{array}{c}\text { Европейский } \\
\text { регион }\end{array}$ & 65,2 & 64,9 & 69,7 & 68,2 & 64,3 & 62,7 & 59,3 & 53,1 & 51,6 & 45,1 \\
\hline $\begin{array}{c}\text { Американский } \\
\text { регион }\end{array}$ & 21,7 & 23,2 & 19,4 & 20,5 & 23 & 22,4 & 28 & 35,6 & 37,8 & 39,2 \\
\hline $\begin{array}{c}\text { Восточно- } \\
\text { Средиземно- } \\
\text { морский реги- } \\
\text { он }\end{array}$ & 3,3 & 2,6 & 2,4 & 2,3 & 2,2 & 1,9 & 1,5 & 1,4 & 1,3 & 1,6 \\
\hline $\begin{array}{c}\text { Юго- } \\
\text { Восточная } \\
\text { Азия }\end{array}$ & 4,7 & 4 & 3,3 & 2,8 & 2,5 & 2,2 & 1,6 & 1,2 & 2,5 & 6,7 \\
\hline $\begin{array}{c}\text { Африканский } \\
\text { регион }\end{array}$ & 0,6 & 0,3 & 0,4 & 1,2 & 3,1 & 5,4 & 5 & 4,2 & 2,1 & 0,9 \\
\hline
\end{tabular}




\section{Американский регион}

В регионе на анализируемой неделе отмечен рост числа новых случаев заболевания на $51 \%$ в сравнении с предыдущей неделей (рис. 4).

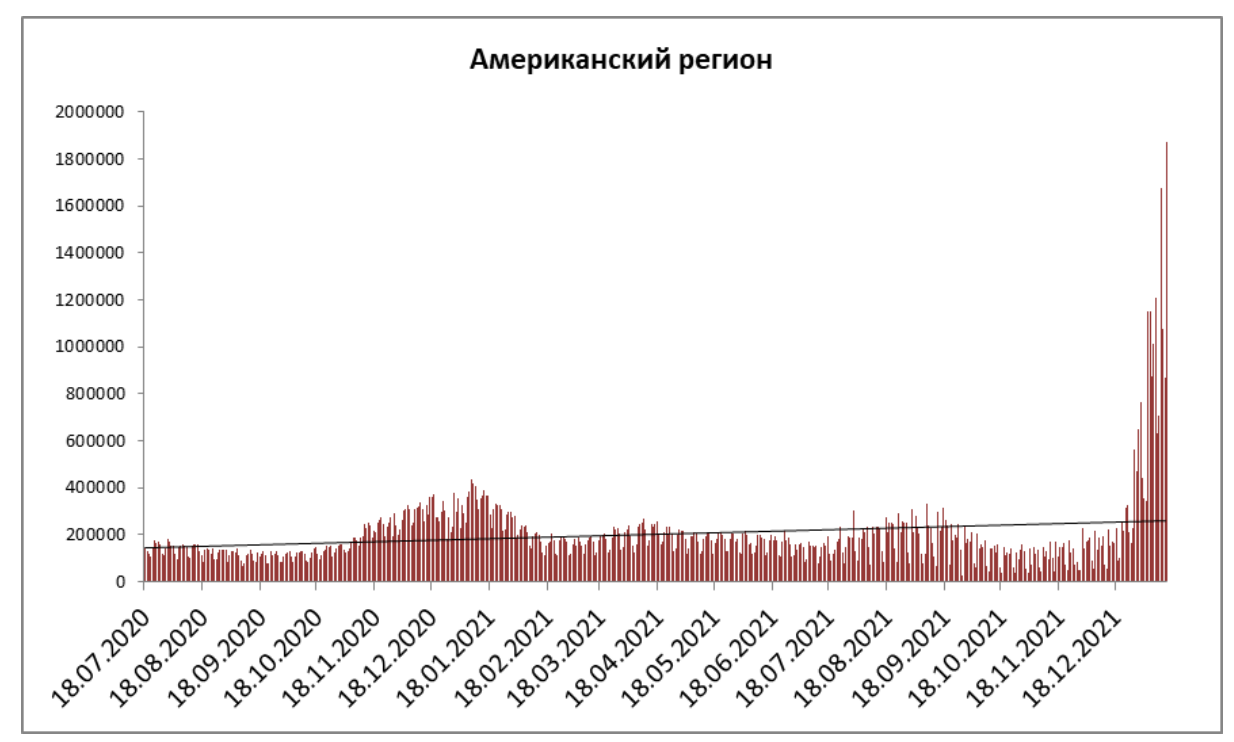

Рисунок 4 - Динамика ежедневного прироста новых случаев в Американском регионе

Количество стран региона, в которых зафиксирован рост числа новых случаев за неделю составило 32; наибольший по сравнению с предыдущей неделей - в Бразилии, Перу, на Кубе и в Гватемале (таб. 3).

Таблица 3 - Страны с максимальным увеличением количества случаев, зарегистрированных за неделю (при сравнении недели с 1 по 7 января и недели с 8 по 14 января) 


\begin{tabular}{|c|c|c|c|c|c|}
\hline \multirow{3}{*}{ Страна } & \multicolumn{4}{|c|}{ Зарегистрировано } & \multirow{3}{*}{ 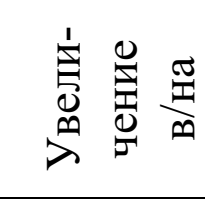 } \\
\hline & \multicolumn{2}{|c|}{ с 1 по 7 января } & \multicolumn{2}{|c|}{ с 8 по 14 января } & \\
\hline & абс. число & на 1 млн & абс. число & на 1 млн & \\
\hline Бразилия & 46603 & 219,3 & 493925 & 2324 & в $10,6 \mathrm{pa}$ \\
\hline Перу & 31049 & 965,4 & 121806 & 3787 & в 3,9 раз \\
\hline Куба & 4996 & 440,8 & 18222 & 1608 & в 3,6 раз \\
\hline Гватемала & 4168 & 235,8 & 14589 & 825 & в 3,5 раза \\
\hline
\end{tabular}

На анализируемой неделе среди стран региона по числу еженедельно выявляемых случаев доминирует США. Удельный вес новых случаев в США в общей заболеваемости Американского региона за неделю составил 69,8\% (рис. $5)$.

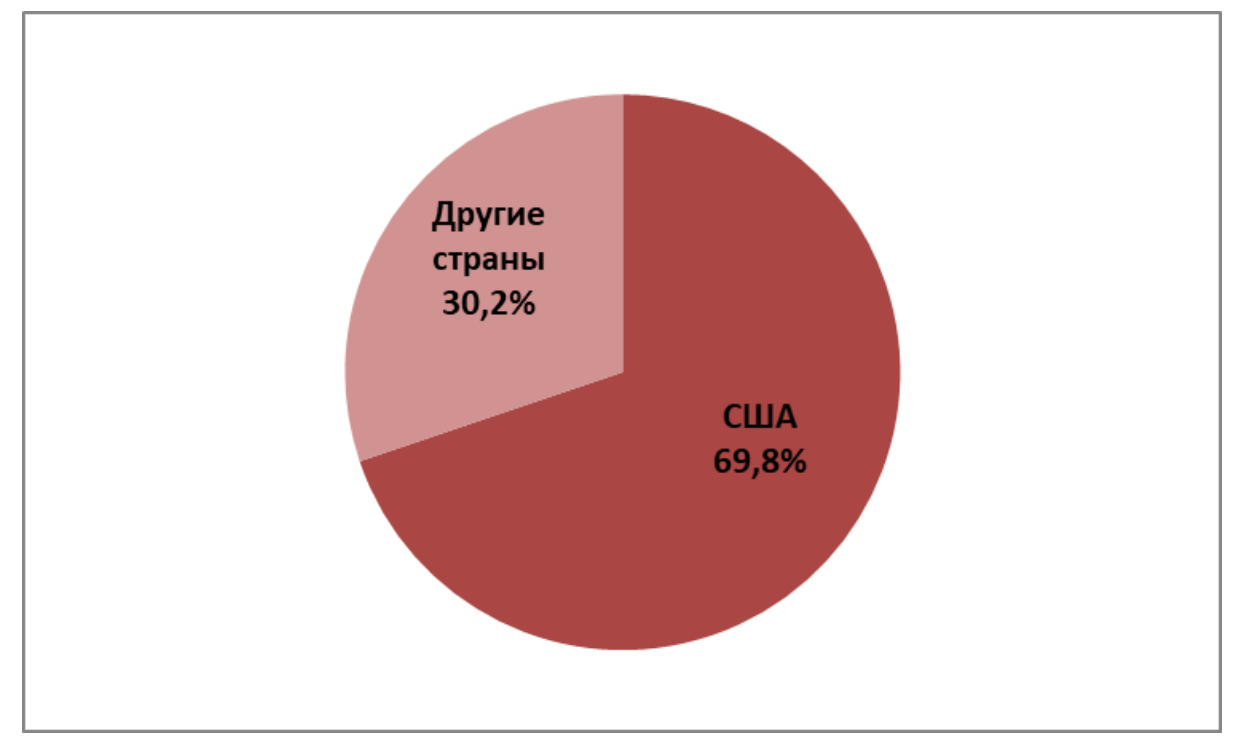

Рисунок 5 - Доля США и других стран в количестве случаев, зарегистрированных за отчетную неделю

Наибольшее число заболевших в регионе на 1 млн населения за последнюю неделю зарегистрировано в Сен-Китс и Невисе (17425), Аргентине (17086) и США (17006). Наибольшее число летальных исходов на 1 млн населения за последнюю неделю зарегистрировано в Тринидаде и Тобаго (102), США (38) и Сент-Люсии (33). 
В настоящее время наблюдается резкое ухудшение эпидситации с COVID19 в Бразилии (рис. 6). Министр здравоохранения Бразилии сообщил, что омикрон-штамм в краткие сроки стал доминирующим в стране. Согласно статистике лабораторных исследований, на омикрон-штамм приходится более 92\% новых положительных результатов тестов. Распространение омикрон-штамма привело к переполнению центров неотложной помощи в Сан-Паулу. В связи с ростом заболеваемости Бразильская ассоциация диагностической медицины рекомендовала проводить тестирование только у пациентов с тяжелыми симптомами.

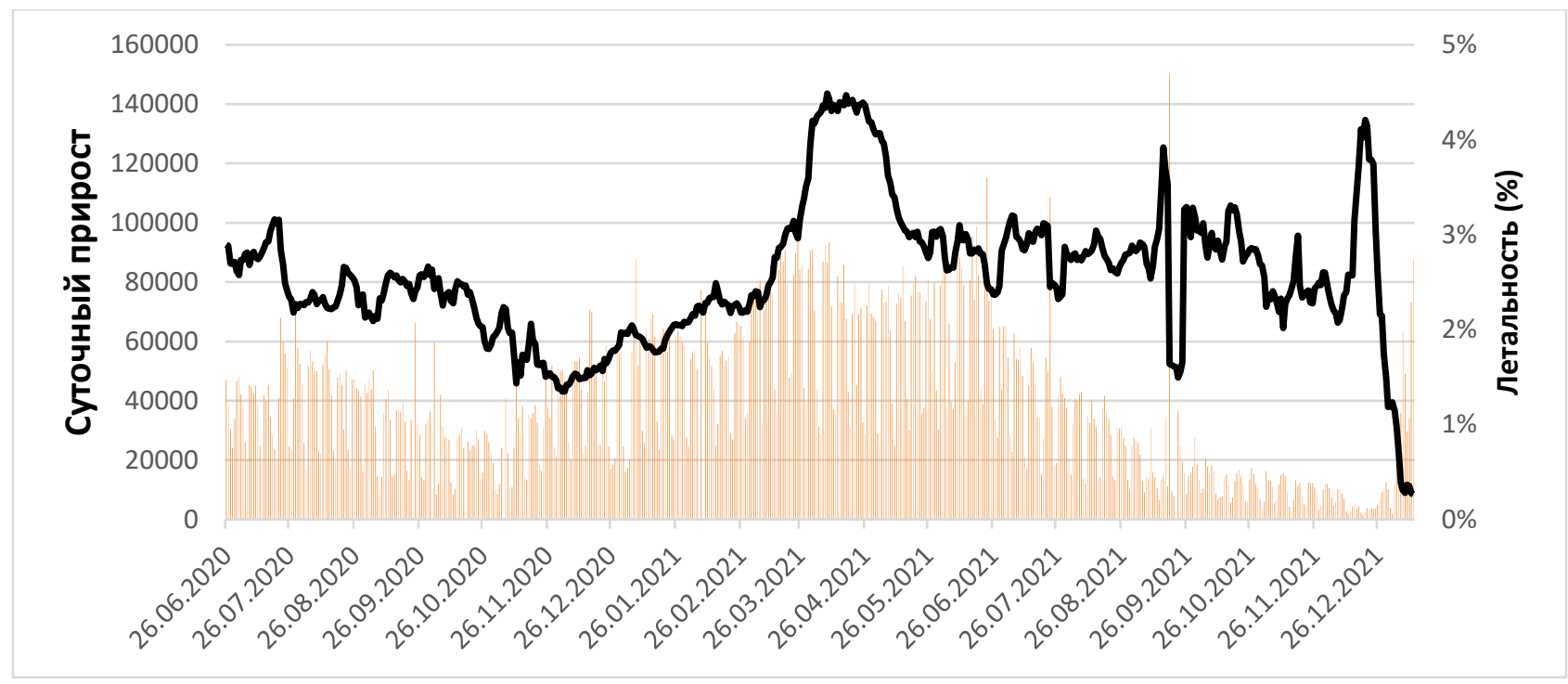

Рисунок 6 - Динамика ежесуточного прироста новых случаев заболевания и летальности в Бразилии (как отношения средних показателей прироста смертей и случаев за 7-дневный период)

В США в настоящее время наблюдается критическая эпидситуация с COVID-19 (рис. 7). Суточный прирост заболевших в США вырос почти втрое за последние две недели на фоне распространения омикрон-штамма, достигнув рекордного по всему миру показателя в 1,35 млн 11 января. В больницах НьюЙорка почти у всех пациентов диагностирован COVID-19. Массово инфицируется медперсонал. Число госпитализаций с COVID-19 в США достигло рекорд- 
ного уровня. Штаты Делавэр, Иллинойс, Мэн, Мэриленд, Миссури, Огайо, Пенсильвания, Вермонт, Вирджиния и Висконсин, а также округ Колумбия, Американские Виргинские острова и Пуэрто-Рико сообщали о рекордном числе госпитализаций с COVID-19 последнюю неделю. Из 81 тыс. коек в палатах интенсивной терапии, доступных в США по всей стране, сейчас заняты почти 65 тыс. коек, из них 24 тыс. коек - пациентами с COVID-19. По всей стране наблюдаются проблемы со своевременной выдачей результатов тестирования, особенно в крупных городах.

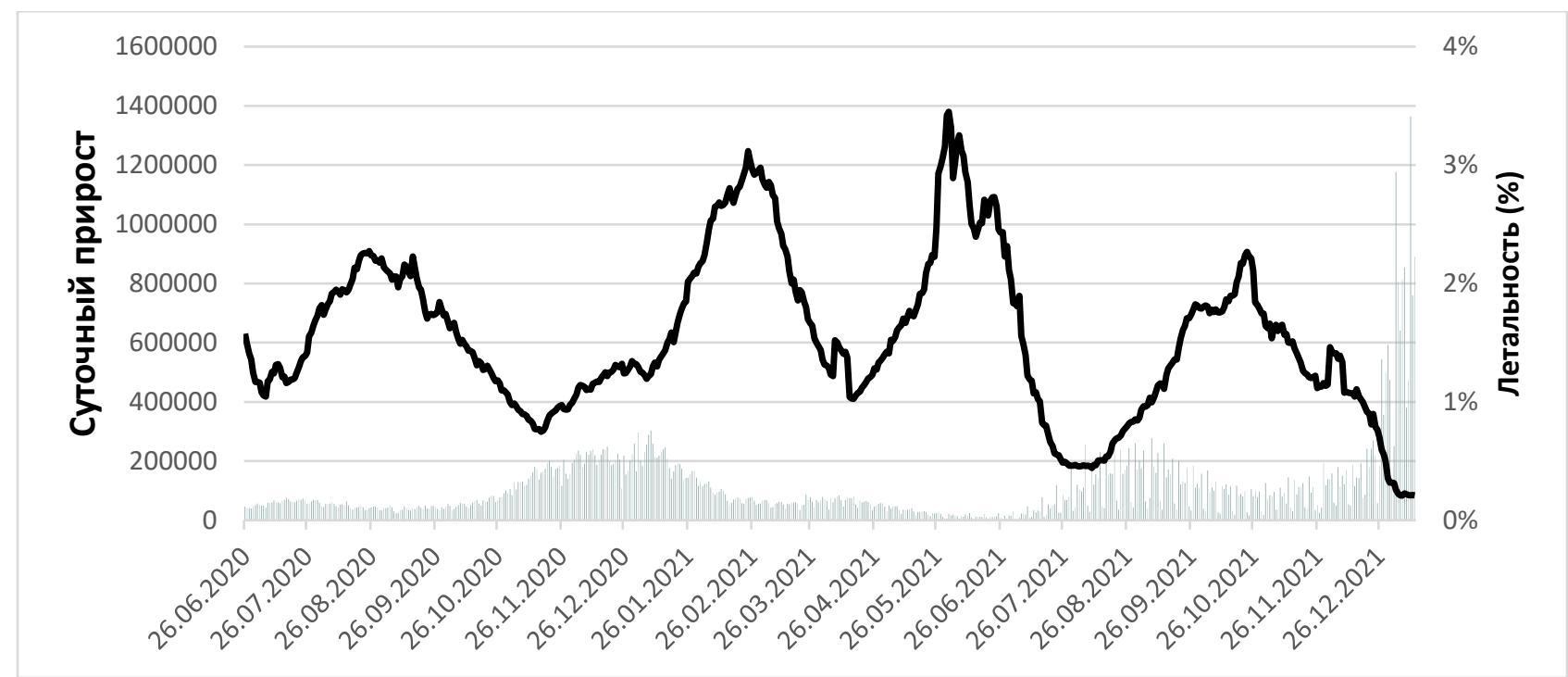

Рисунок 7 - Динамика ежесуточного прироста новых случаев в США (как отношения средних показателей прироста смертей и случаев за 7-дневный период)

\section{Европейский регион}

В Европейском регионе на анализируемой неделе отмечен рост числа новых случаев заражения на $28,1 \%$ в сравнении с предыдущей неделей (рис. 8 ). 


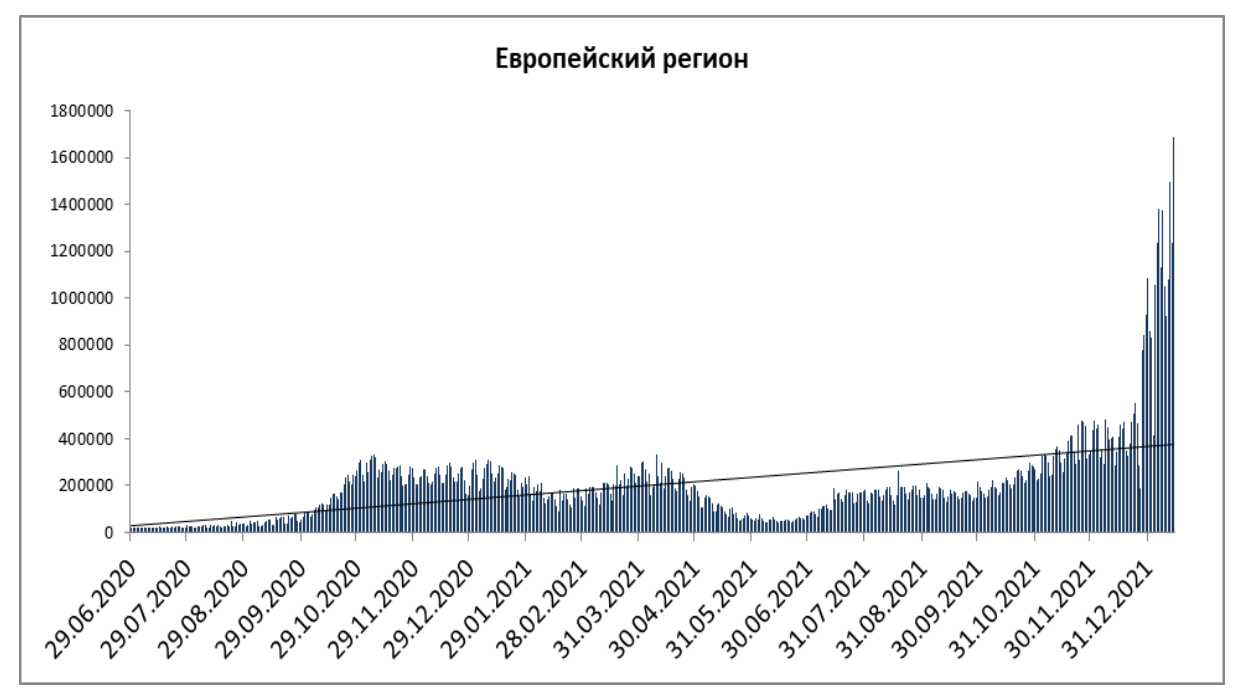

Рисунок 8 - Динамика ежедневного прироста новых случаев в Европейском регионе

Рост заболеваемости за неделю отмечен в 45 из 56 стран региона, наибольший - в Казахстане, Узбекистане, Киргизии и Израиле (таб. 4).

Таблица 4 - Страны с максимальным увеличением количества случаев, зарегистрированных за неделю (при сравнении недели с 1 по 7 января и недели с 8 по 14 января)

\begin{tabular}{|c|c|c|c|c|c|}
\hline \multirow{3}{*}{ Страна } & \multicolumn{4}{|c|}{ Зарегистрировано } & \multirow{3}{*}{ 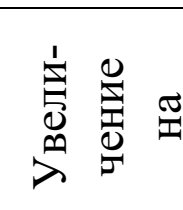 } \\
\hline & \multicolumn{2}{|c|}{ с 1 по 7 января } & \multicolumn{2}{|c|}{ с 8 по 14 января } & \\
\hline & абс. число & на 1 млн & абс. число & на 1 млн & \\
\hline Казахстан & 2768 & 146,7 & 23777 & 1261 & в 8,6 ра3 \\
\hline Узбекистан & 738 & 21,3 & 2966 & 86 & в 4 раза \\
\hline Киргизия & 604 & 92,6 & 2383 & 365 & в 3,9 ра3 \\
\hline Израиль & 68402 & 7487 & 247057 & 27042 & в 3,6 ра3 \\
\hline
\end{tabular}

Наибольшее число инфицированных на 1 млн населения в регионе за неделю зафиксировано в Ирландии (30975), на Кипре (29932) и во Франции 
(29908). Наибольшее число летальных исходов на 1 млн населения за последнюю неделю отмечено в Болгарии (79), Грузии (74) и Хорватии (59).

Неблагоприятная эпидситуация с COVID-19 в настоящее время регистрируется в Швеции (рис. 10). Уровень заболеваемости в стране находится на исторически высоком уровне. Правительство Швеции объявило об ужесточении ограничений с 13 января: взрослым гражданам рекомендовано по возможности работать удаленно, собрания и вечеринки ограничиваются 8-ю участниками, а заведения общепита будут работать до 23:00. Также на общественных мероприятиях, где не применяют систему COVID-паспортов, смогут находиться максимум 50 человек. Новые ограничения будут действовать около месяца.

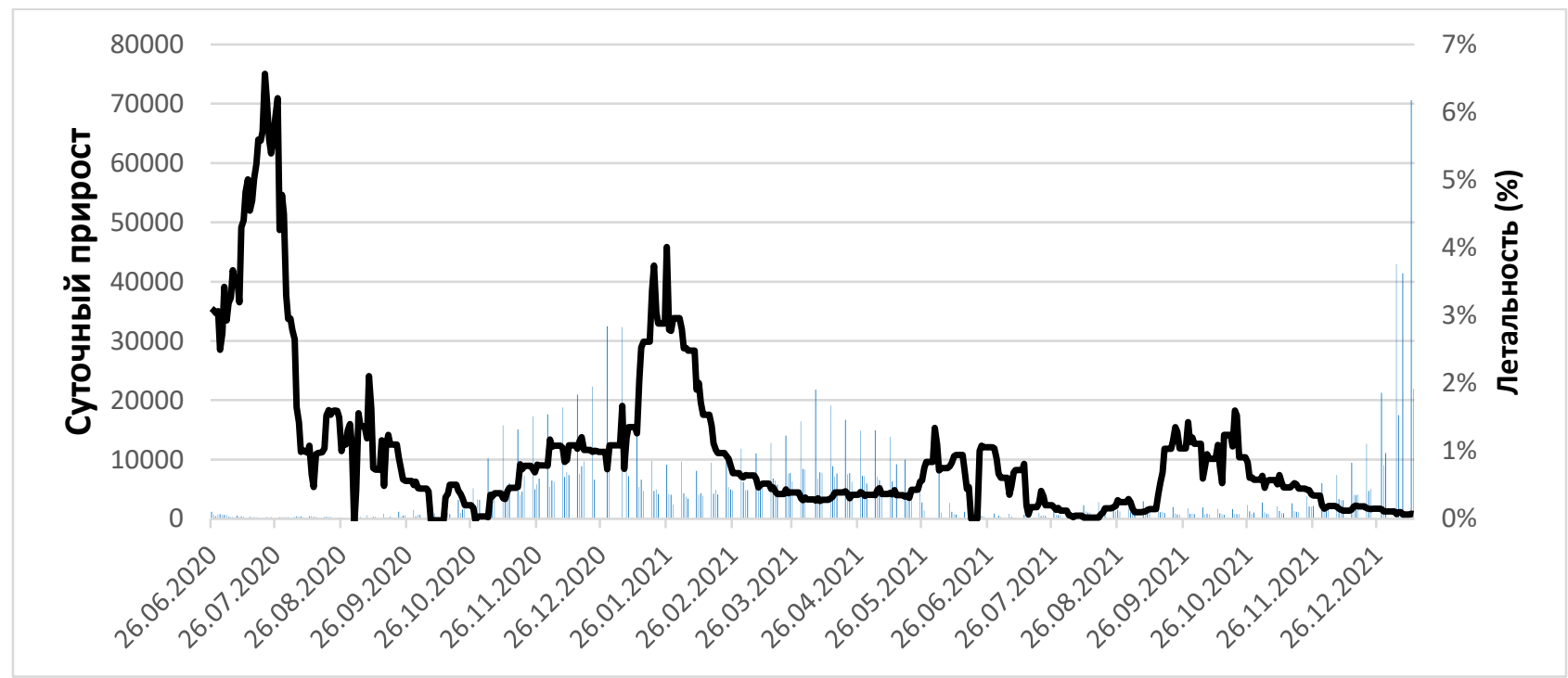

Рисунок 9 - Динамика ежесуточного прироста новых случаев заболевания и летальности в Швеции (как отношения средних показателей прироста смертей и случаев за 7-дневный период)

В настоящее время значительный рост заболеваемости COVID-19 наблюдается также в Словении (рис. 9). В стране 12 января был зафиксирован рекордный суточный прирост случаев заражения за период пандемии -7423 . В связи с этим, власти Словении ужесточили ограничительные меры в стране. Общественным транспортом теперь смогут пользоваться только лица с доку- 
ментом о вакцинации от COVID-19, перенесенном заболевании или отрицательном результате теста - COVID-сертификатом. Ношение маски в транспорте обязательно. При этом власти Словении сократили срок обязательного карантина на дому с 10 до 7 дней.

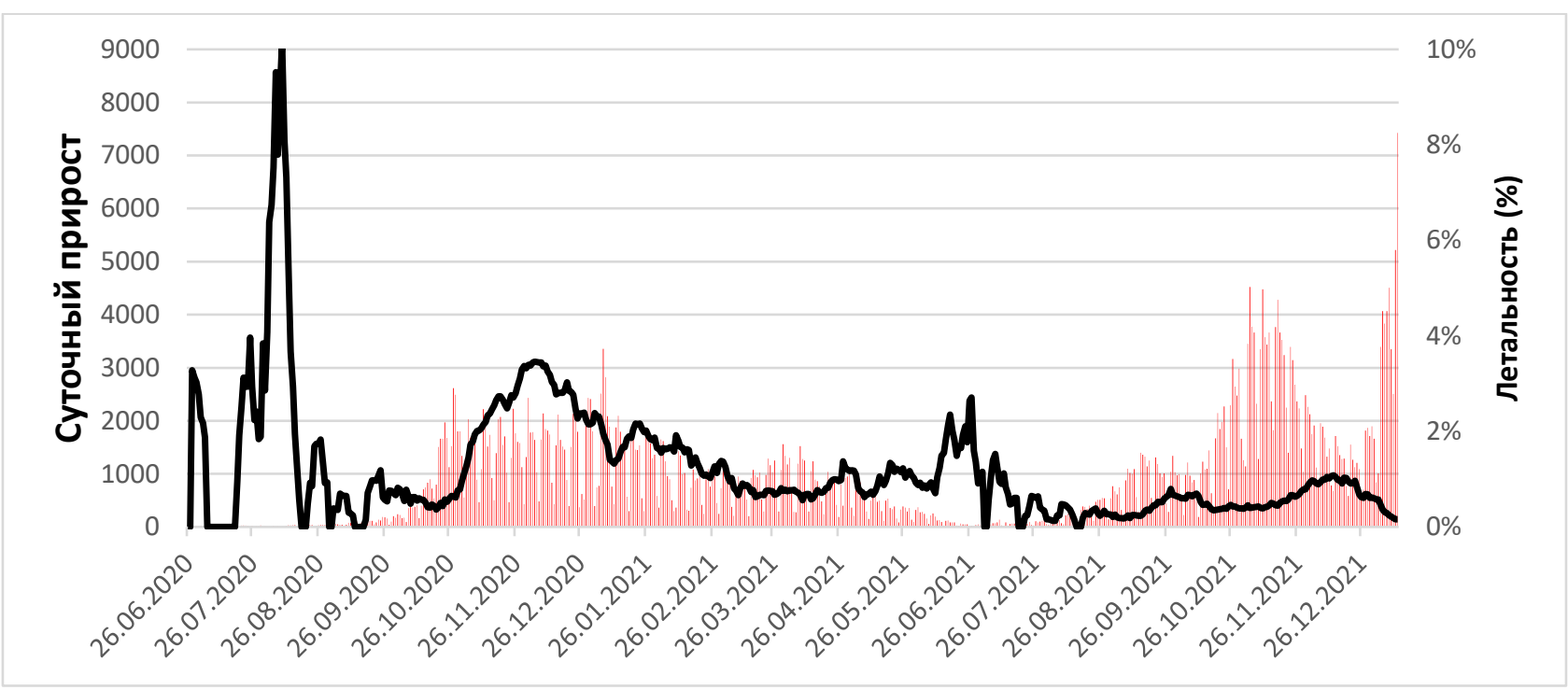

Рисунок 10 - Динамика ежесуточного прироста новых случаев заболевания и летальности в Словении (как отношения средних показателей прироста смертей и случаев за 7-дневный период)

Доля выявленных случаев в странах СНГ от всех зарегистрированных в Европейском регионе составила $2,3 \%$ - снижение на $0,1 \%$ по сравнению с прошлой неделей (рис. 11). 


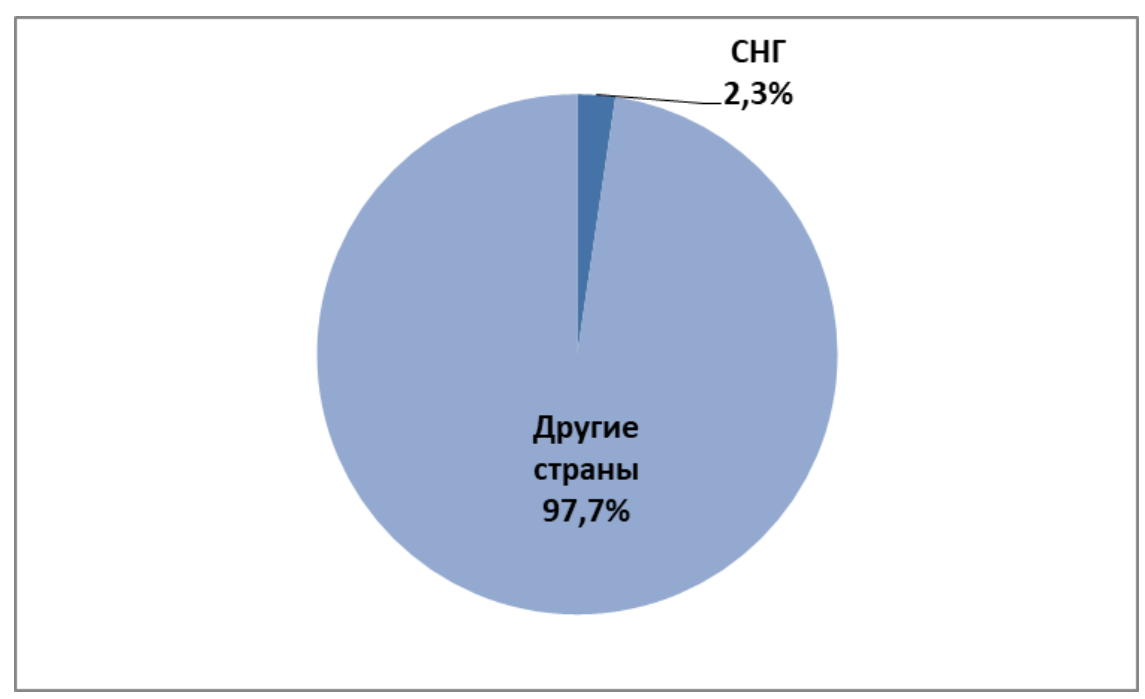

Рисунок 11 - Доля стран СНГ и других стран в количестве случаев, зарегистрированных за отчетную неделю в Европейском регионе

\section{Западно-Тихоокеанский регион}

На анализируемой неделе в Западно-Тихоокеанском регионе отмечен рост числа регистрируемых случаев на $101,8 \%$ в сравнении с прошлой неделей (рис. 12).

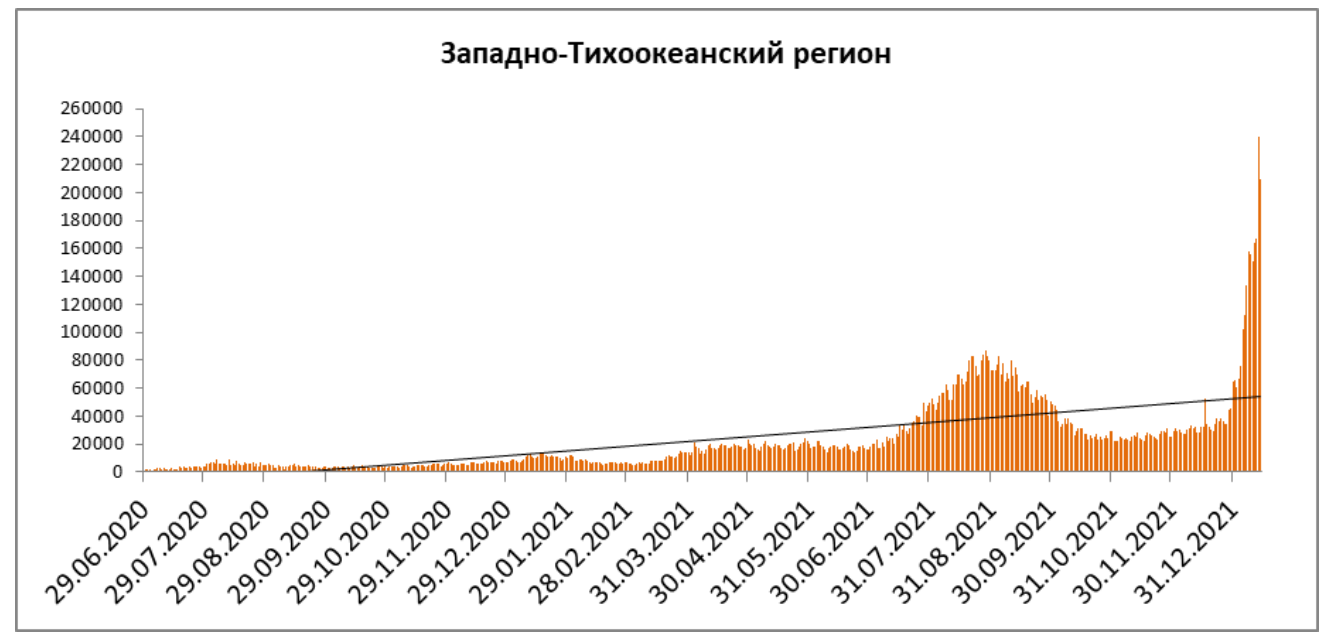

Рисунок 12 - Динамика ежедневного прироста новых случаев в Западно-Тихоокеанском регионе

В 13 странах региона зафиксирован рост числа новых случаев за неделю, наибольший - в Японии и на Филиппинах (таб. 5). 
Таблица 5 - Страны с максимальным увеличением количества случаев, зарегистрированных за неделю (при сравнении недели с 1 по 7 января и недели с 8 по 14 января)

\begin{tabular}{|c|c|c|c|c|c|}
\hline \multirow{3}{*}{ Страна } & \multicolumn{4}{|c|}{ Зарегистрировано } & \multirow{3}{*}{ 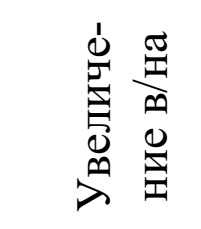 } \\
\hline & \multicolumn{2}{|c|}{ с 1 по 7 января } & \multicolumn{2}{|c|}{ с 8 по 14 января } & \\
\hline & абс. число & на 1 млн & абс. число & на 1 млн & \\
\hline Япония & 9959 & 79 & 66664 & 529 & в 6,7 раз \\
\hline Филиппины & 47657 & 435 & 203492 & 1858 & в 4,3 раза \\
\hline
\end{tabular}

На Австралию приходится 61,6\% от всех выявленных случаев за неделю в Западно-Тихоокеанском регионе (рис. 13).

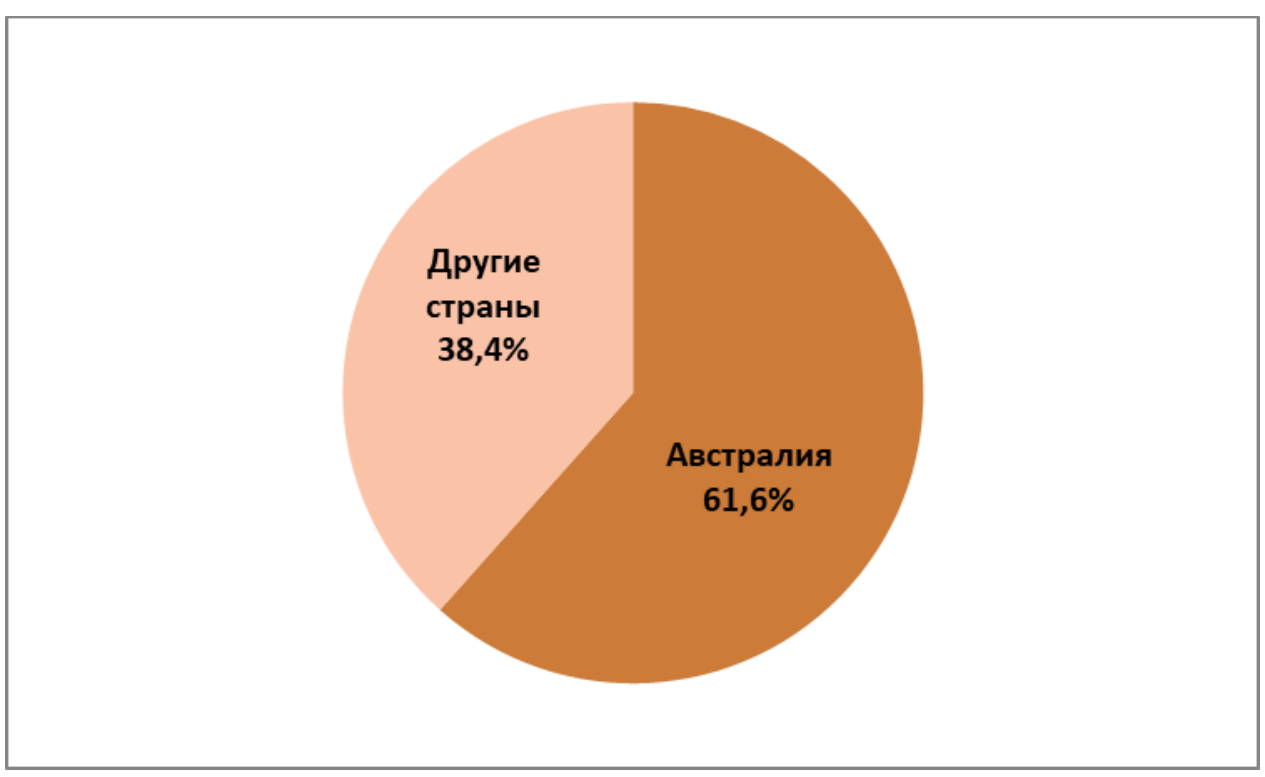

Рисунок 13 - Доля Австралии и других стран в количестве случаев, зарегистрированных за отчетную неделю.

В регионе наибольшее число новых случаев заражения на 1 млн населения за неделю зарегистрировано в Австралии (29539) и на Фиджи (3193). Наибольшее число летальных исходов на 1 млн населения зафиксировано на Фиджи (19) и во Вьетнаме (16). 
В настоящее время наблюдается ухудшение эпидситуации с COVID-19 в Австралии (рис. 14). Стремительное распространение омикрон-штамма стало причиной введения запрета на въезд в штат Западная Австралия. Власти Западной Австралии объявили остальную часть страны территорией крайнего риска. Отныне в штат могут попасть только члены федерального правительства, парламента или дипломаты. В Новой Южном Уэльсе, по последним данным, выявлено 50 тыс. положительных результатов экспресс-тестов. Власти штата объявили, что жители должны выкладывать результаты своих тестов на антитела через приложение с 1 января.

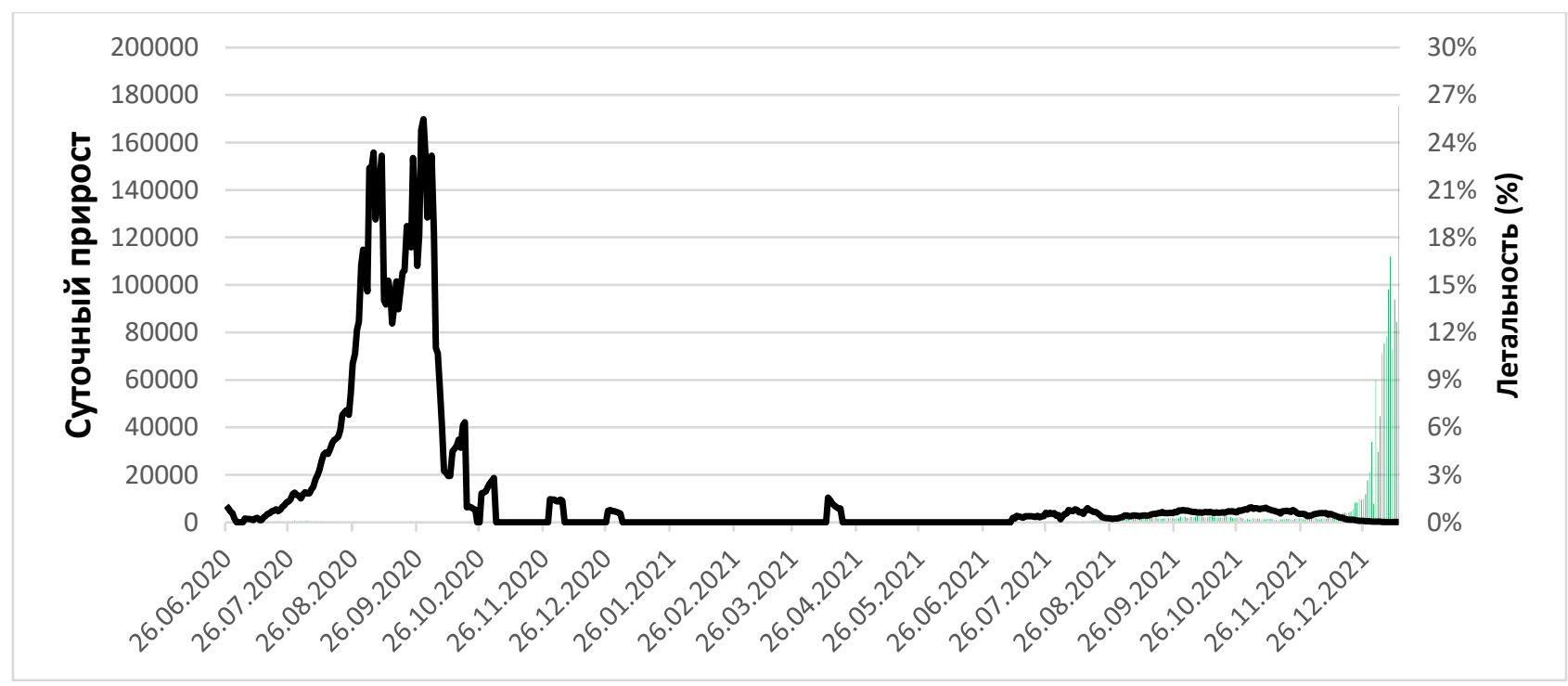

Рисунок 14 - Динамика ежесуточного прироста новых случаев и летальности в Австралии (как отношения средних показателей прироста смертей и случаев за 7-дневный период)

\section{Восточно-Средиземноморский регион}

В регионе на анализируемой неделе наблюдается снижение числа новых случаев заболевания на 81,5 \% в сравнении с прошлой неделей (рис. 15). 


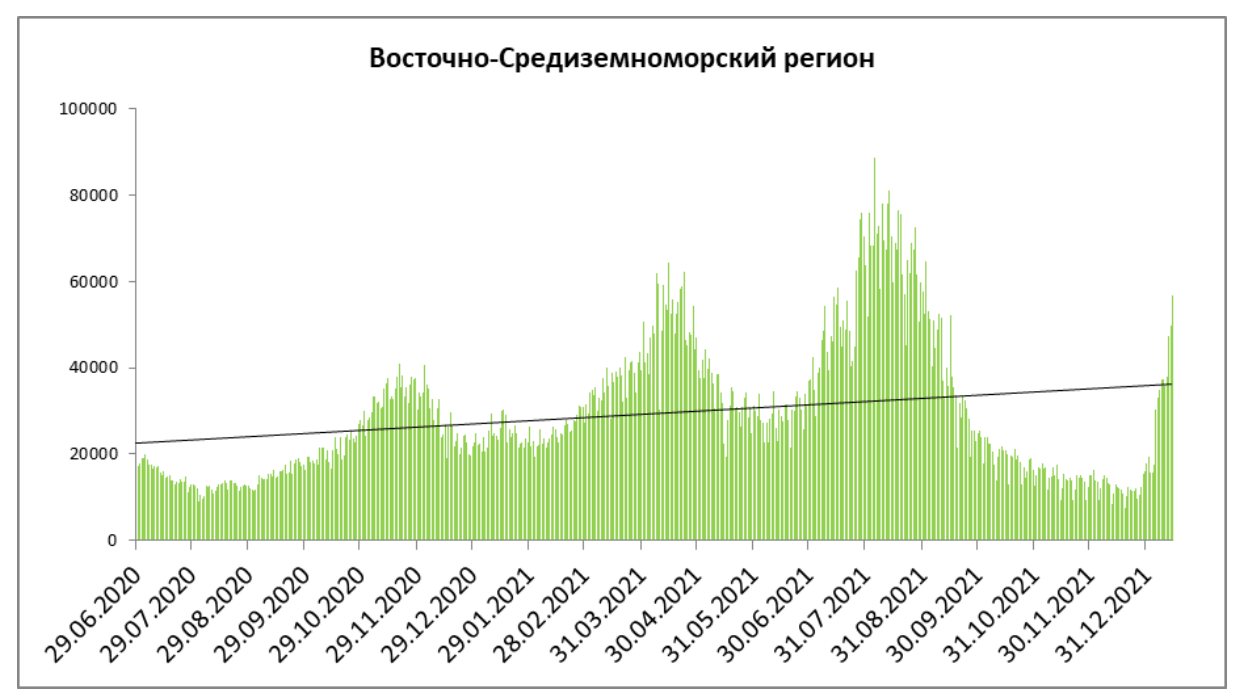

Рисунок 15 - Динамика ежедневного прироста новых случаев в Восточно-

Средиземноморском регионе

За неделю с 8 по 14 января в 18 из 22 стран региона отмечен рост числа новых случаев заражения. Максимальное увеличение недельного прироста зафиксировано в Ираке, Кувейте и Омане (таб. 7).

Таблица 6 - Страны с максимальным увеличением количества случаев, зарегистрированных за неделю (при сравнении недели с 1 по 7 января и недели с 8 по 14 января)

\begin{tabular}{|c|c|c|c|c|c|}
\hline \multirow{2}{*}{ Страна } & \multicolumn{4}{|c|}{ Зарегистрировано } & \multirow{2}{*}{} \\
\cline { 2 - 5 } & \multicolumn{2}{|c|}{ с 1 по 7 января } & \multicolumn{2}{|c|}{ с 8 по 14 января } & \multirow{2}{*}{} \\
\cline { 1 - 5 } & абс. число & на 1 млн & абс. число & на 1 млн & \multirow{2}{*}{ Ирак } \\
\cline { 1 - 5 } Кувейт & 2412 & 61,4 & 9092 & 231 & \multirow{2}{*}{ в 3,7 раз } \\
\hline Оман & 8824 & 2097 & 25975 & 6174 & в 2,9 раз \\
\hline
\end{tabular}

На Ливан и Марокко приходится 30,7\% от всех выявленных случаев за неделю с 8 по 14 января в Восточно-Средиземноморском регионе (рис. 16). 


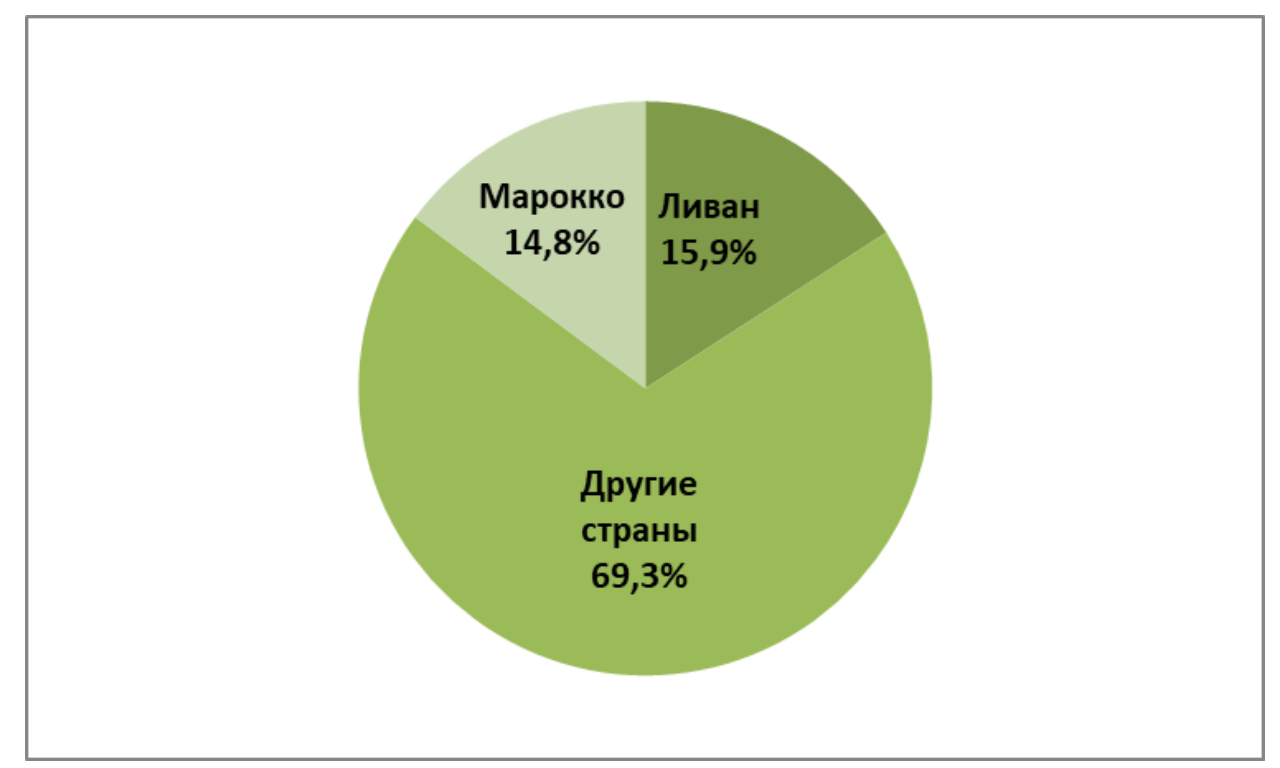

Рисунок 16 - Удельный вес Ливана, Марокко и других стран в структуре случаев в Восточно-Средиземноморском регионе

Наибольшее число заболевших на 1 млн населения за последнюю неделю зарегистрировано в Катаре (9738) и Бахрейне (7216). Наибольшее число летальных исходов на 1 млн населения за последнюю неделю зарегистрировано в Ливане (16) и Иордании (13).

В Кувейте в настоящее время наблюдается неблагоприятная эпидситуация с COVID-19 (рис.17). Власти страны решили ужесточить ограничительные меры в стране из-за роста заболеваемости. Согласно планам правительства, на предприятиях в стране сократят до 50\% число работников, работающих в офисах. Также власти призывают владельцев компаний по максимуму сократить пребывание сотрудников на рабочих местах. Кроме того, в Кувейте намерены в срочном порядке привить от COVID-19 медицинских работников, сотрудников детских и спортивных учреждений, а также работников сферы услуг. 


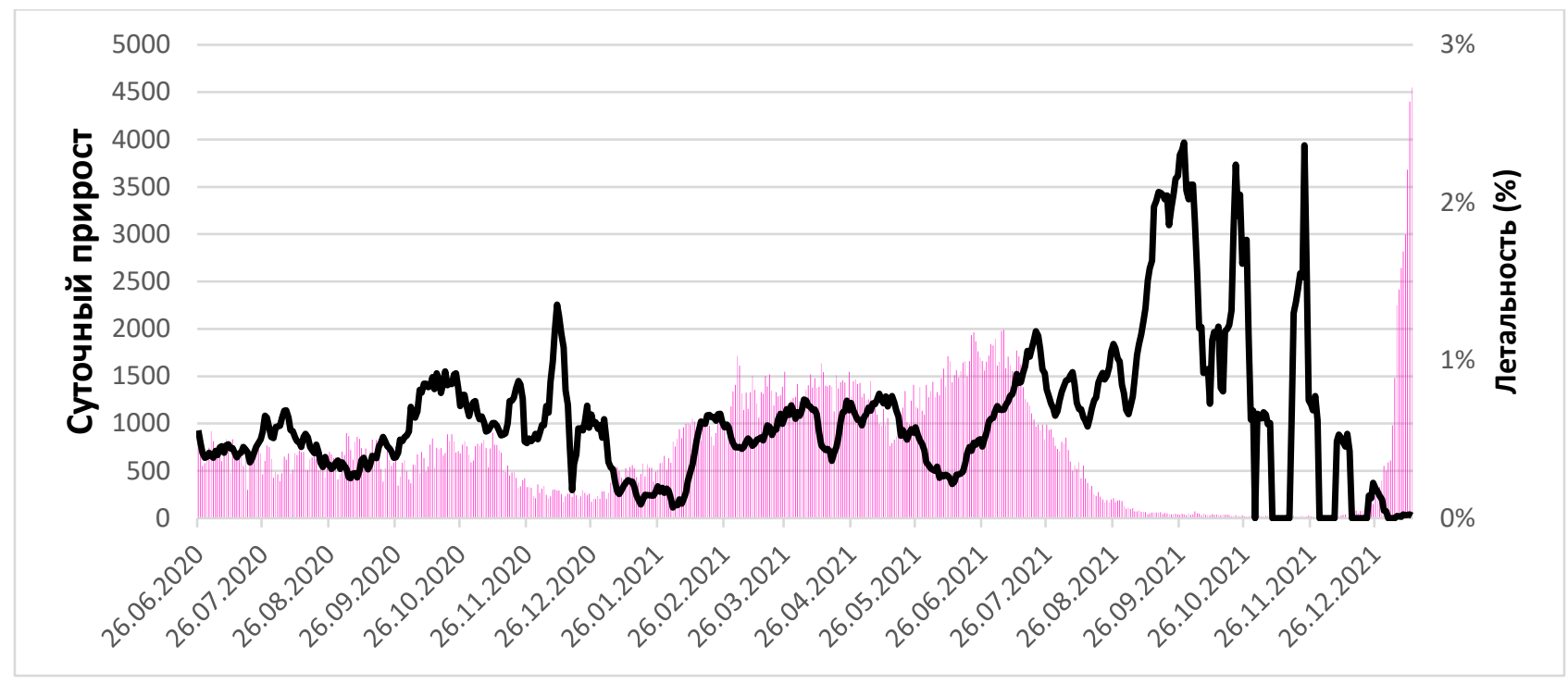

Рисунок 17 - Динамика ежесуточного прироста новых случаев заболевания и летальности в Кувейте (как отношения средних показателей прироста смертей и случаев за 7-дневный период).

\section{Юго-Восточная Азия}

В регионе на анализируемой неделе наблюдается рост числа новых случаев на 292,8\% в сравнении с прошлой неделей (рис.18).

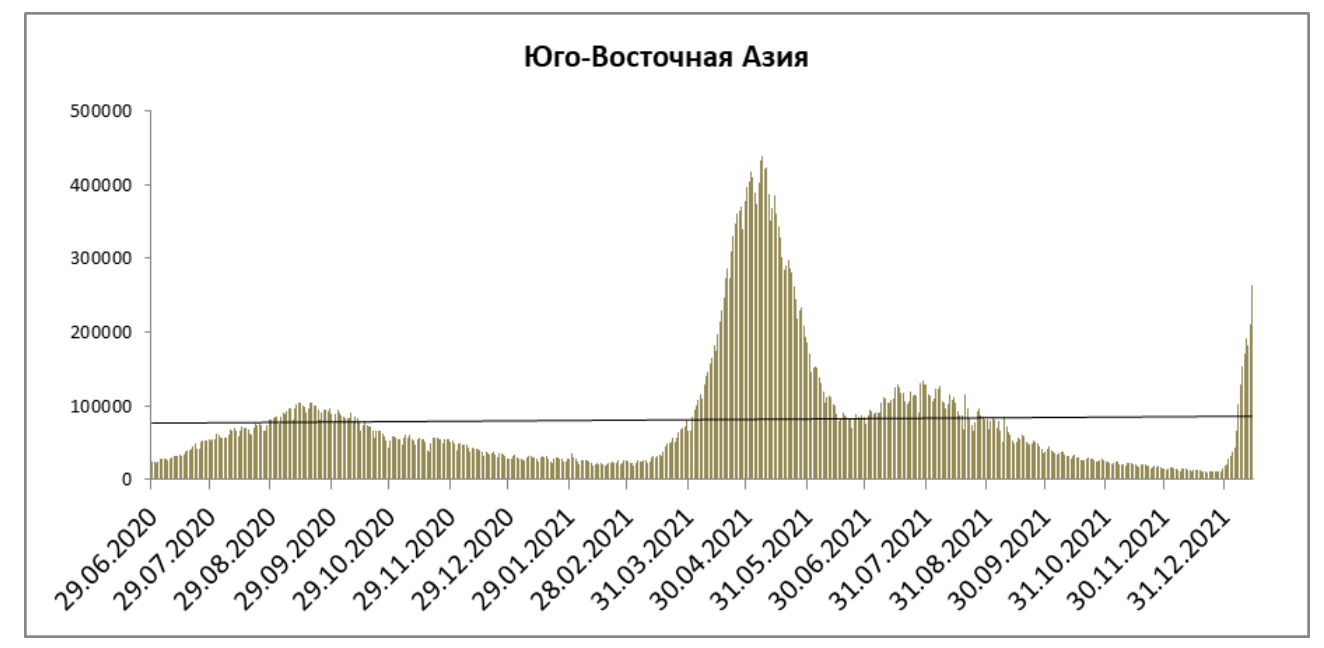

Рисунок 18 - Динамика ежедневного прироста новых случаев в Юго-Восточной Азии 
Рост заболеваемости за последнюю неделю отмечен во всех 10 странах региона, наибольший - в Непале и Индии .

Таблица 7 - Страны с максимальным увеличением количества случаев, зарегистрированных за неделю (при сравнении недели с 1 по 7 января и недели с 8 по 14 января)

\begin{tabular}{|c|c|c|c|c|c|}
\hline \multirow{3}{*}{ Страна } & \multicolumn{4}{|c|}{ Зарегистрировано } & \multirow{3}{*}{ 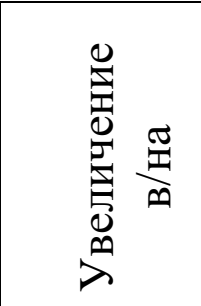 } \\
\hline & \multicolumn{2}{|c|}{ с 1 по 7 января } & \multicolumn{2}{|c|}{ с 8 по 14 января } & \\
\hline & абс. число & на 1 млн & абс. число & на 1 млн & \\
\hline Непал & 2273 & 79,5 & 10817 & 378 & в 4,7 раз \\
\hline Индия & 287246 & 208 & 1208641 & 874 & в 4,2 раза \\
\hline
\end{tabular}

На Индию приходится 92,7\% от всех выявленных за неделю случаев в Юго-Восточной Азии в период с 8 по 14 января (рис.19).

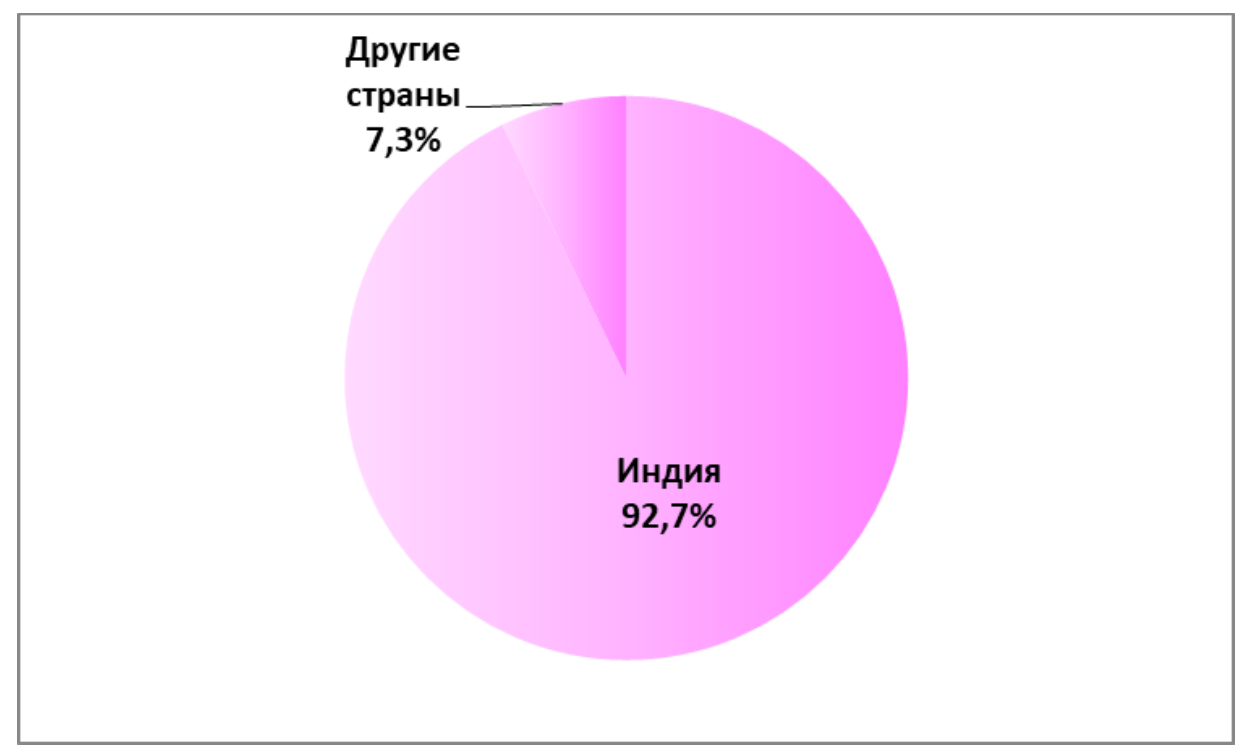

Рисунок 19 - Доля Индии и других стран региона в количестве случаев, зарегистрированных за отчетную неделю 
Наибольшее число заболевших на 1 млн населения за последнюю неделю зарегистрировано на Мальдивах (6184) и в Индии (874). Наибольшее число летальных исходов на 1 млн населения за последнюю неделю в регионе зарегистрировано на Шри-Ланке (4) и в Индии (2).

В настоящее время наблюдается ухудшение эпидситуации с COVID-19 в Индии (рис. 20). Индийские власти сообщили том, что рост заболеваемости связан с распространением омикрон-штамма, и призвали население принимать превентивные меры. Правительство Индии также ужесточило правила въезда для иностранных туристов, в том числе россиян. Согласно новым правилам, с 11 января все путешественники, въезжающие в страну, вне зависимости от статуса вакцинации обязаны пройти 7-дневный карантин. После его окончания отдыхающие должны сдать ПЦР-тест за свой счет. Кроме того, на Гоа введен комендантский час с 23:00 до 6:00, ограничивающий перемещение туристов. Сроки снятия ограничений пока не уточняются.

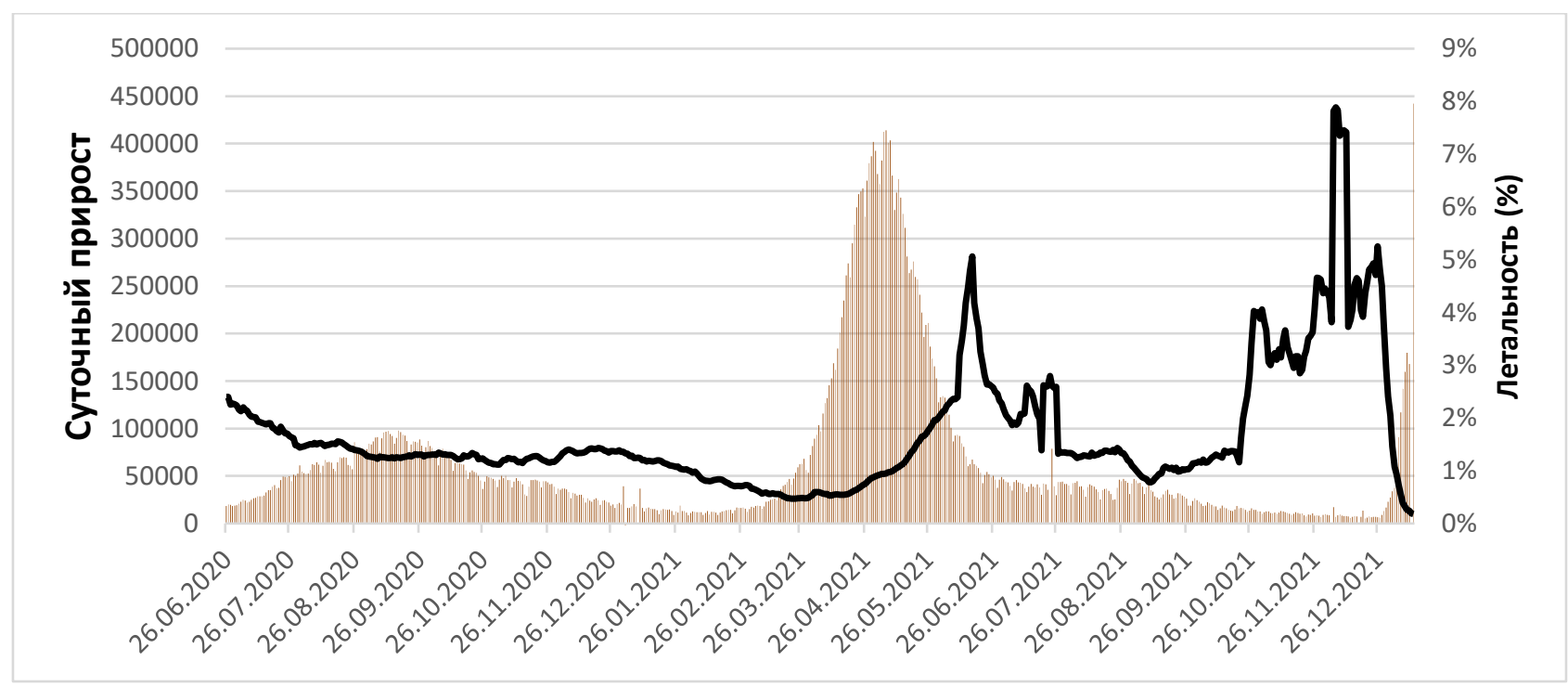

Рисунок 20 - Динамика ежесуточного прироста новых случаев заболевания и летальности в Индии (как отношения средних показателей прироста смертей и случаев за 7-дневный период) 


\section{Африканский регион}

В регионе на анализируемой неделе наблюдается снижение числа новых случаев заболевания на 27,1\% в сравнении с прошлой неделей (рис. 21).

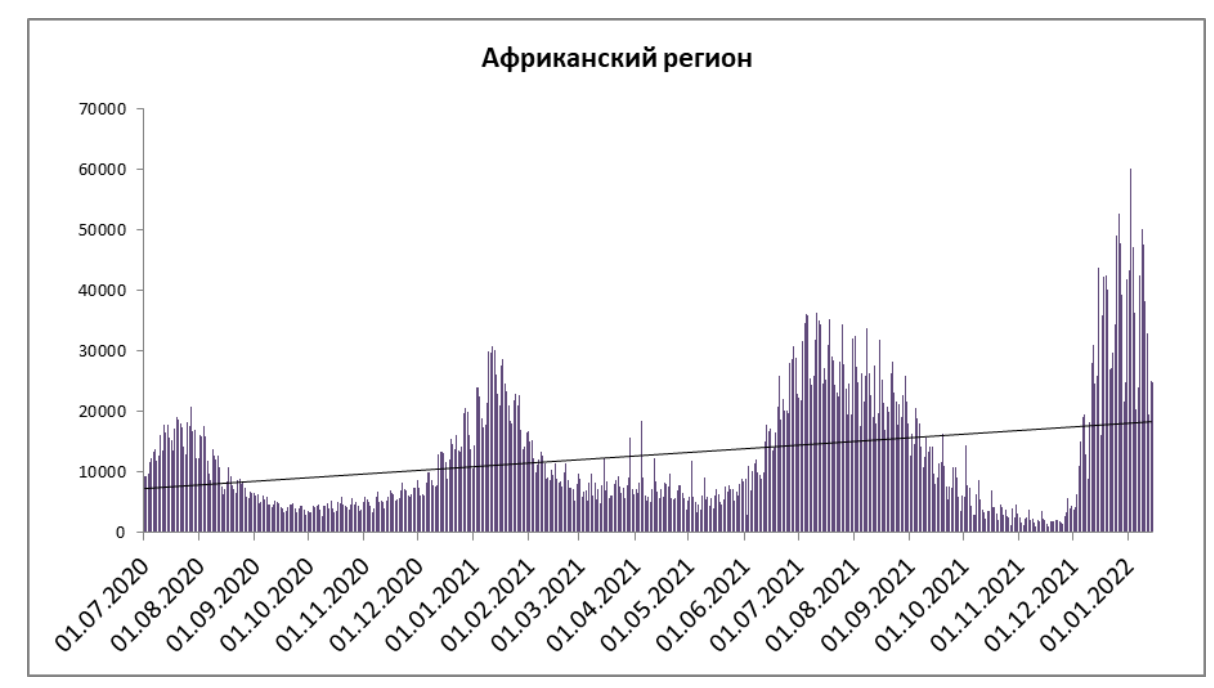

Рисунок 21 - Динамика ежедневного прироста новых случаев в Африканском регионе

В 14 из 48 стран Африканского региона зарегистрирован рост числа новых случаев. Максимальное увеличение еженедельного прироста новых случаев по сравнению с предшествующей неделей демонстрируют Экваториальная Гвинея, Сан-Томе и Принсипи и Нигер (таб. 9).

Таблица 8 - Страны с максимальным увеличением количества случаев, зарегистрированных за неделю (при сравнении недели с 1 по 7 января и недели с 8 по 14 января). 


\begin{tabular}{|c|c|c|c|c|c|}
\hline \multirow{2}{*}{ Страна } & \multicolumn{4}{|c|}{ Зарегистрировано } & \multirow{2}{*}{$\begin{array}{c}\text { Увеличе- } \\
\text { ние в/на }\end{array}$} \\
\cline { 2 - 5 } & \multicolumn{2}{|c|}{ с 1 по 7 января } & \multicolumn{2}{|c|}{ с 8 по 14 января } & \\
\cline { 2 - 5 } & абс. число & на 1 млн & абс. число & на 1 млн & \\
\hline $\begin{array}{c}\text { Экваториаль- } \\
\text { ная Гвинея }\end{array}$ & 166 & 122,4 & 995 & 734 & в 6 раз \\
\hline $\begin{array}{c}\text { Сан-Томе и } \\
\text { Принсипи }\end{array}$ & 274 & 1274,4 & 1253 & 5828 & \multirow{2}{*}{ в 4,6 раз } \\
\hline Нигер & 259 & 11,6 & 716 & 32 & в 2,8 раз \\
\hline
\end{tabular}

На ЮАР приходится 21,6\% от всех выявленных за неделю случаев в Африканском регионе в период с 8 по 14 января (рис. 22).

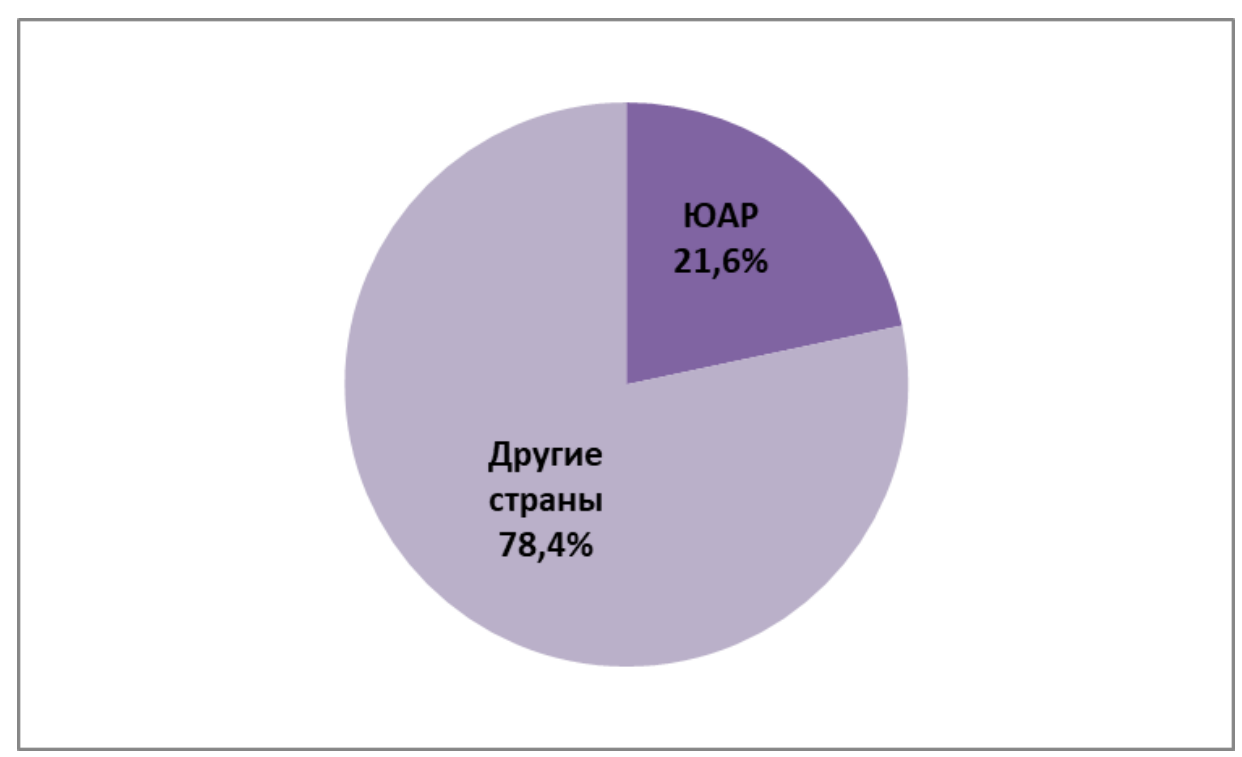

Рисунок 22 - Удельный вес ЮАР и других стран в структуре случаев, зарегистрированных за отчетную неделю в Африканском регионе

Наибольшее число заболевших на 1 млн населения за последнюю неделю зарегистрировано на Сейшелах (42143), в Кабо-Верде (9733) и Сан-Томе и Принсипи (5828). Наибольшее число летальных исходов на 1 млн населения за последнюю неделю зарегистрировано в Намибии (39), Эсватини (23) и на Сейшелах (20). 
Ухудшение эпидситуации с COVID-19 в настоящее время наблюдается в Мавритании (рис.23). Комитет, отвечающий за мониторинг распространения COVID-19 в Мавритании, 8 января ужесточил ограничения на фоне роста заболеваемости. Власти обязывают носить защитные маски в общественных местах, в том числе на рынках, в кафе, ресторанах и в общественном транспорте. Также запрещены общественные собрания. Правительство Мавритании также проведет национальную кампанию по повышению осведомленности об омикронштамме с помощью средств массовой информации.

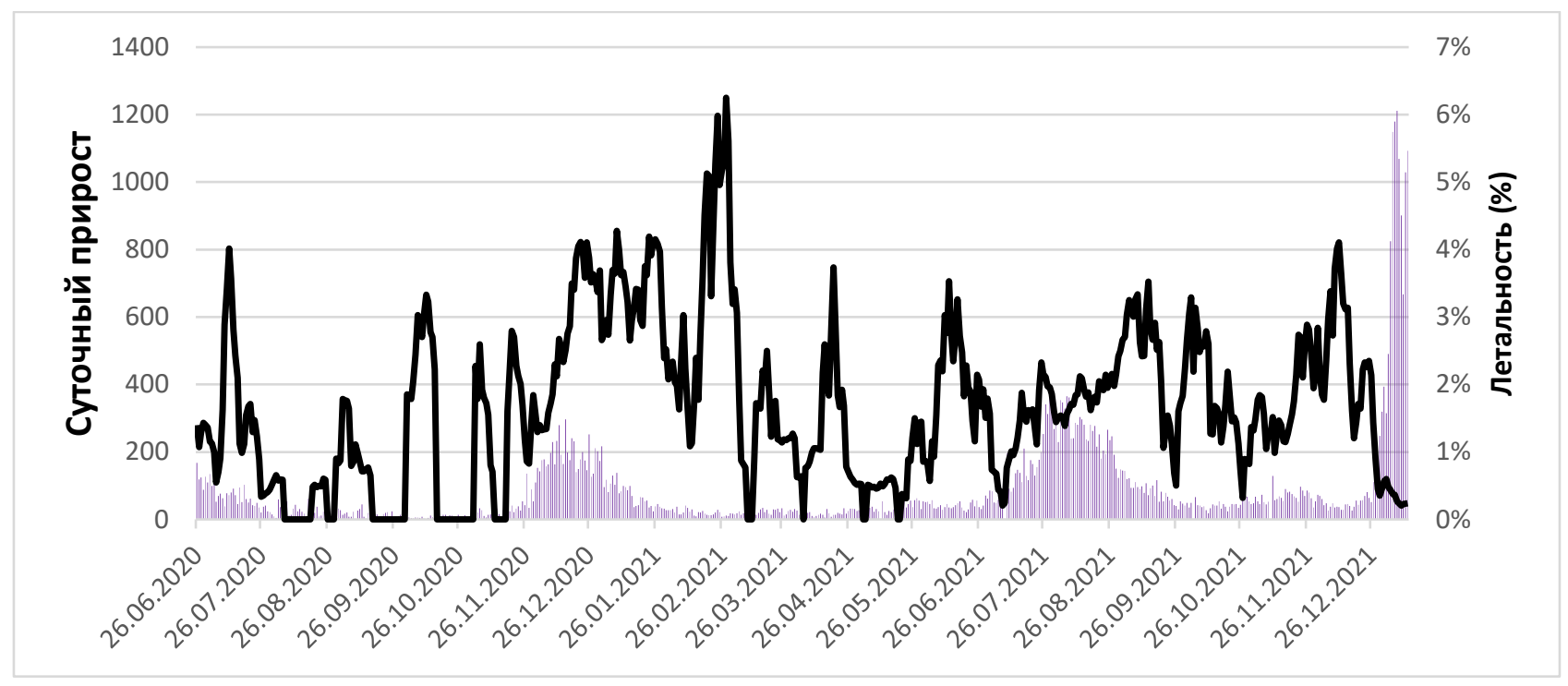

Рисунок 23 - Динамика ежесуточного прироста новых случаев заболевания и летальности в Мавритании (как отношения средних показателей прироста смертей и случаев за 7-дневный период) 